\title{
Intergenerational education as a strategy for promoting active ageing
}

\begin{abstract}
The objective of this article is to present the main results of a study about intergenerational education as a strategy for promoting active ageing. The research took place in the parish of Bonfim, Oporto city, Portugal, and involved a sample of 385 residents, divided into three age groups (young-adults, middle-aged adults and older adults). The data came from the Questionnaire for Assessing Needs, Interests and Potentials for the Development of Intergenerational Programs, from which the following variables were considered: social participation; leisure activities; social support and quality of life. As main results, one can point that older subgroups show less social participation and leisure activities, low social support networks and also low quality of life compared to younger subgroups. A gender effect was also noticed, since the social roles performed across adulthood by man and women result in less social participation of women, less leisure activities, less social support networks and a worse evaluation of their quality of life.
\end{abstract}

Keywords: intergenerational education, lifelong education, active ageing, quality of life, social support, social participation
Volume 4 Issue $3-2019$

\author{
Susana Villas-Boas, ' Albertina L Oliveira, ${ }^{2}$ \\ Natália Ramos, ${ }^{3}$ Inmaculada Montero, ${ }^{4}$ \\ 'Faculty of Psychology and Education Sciences, University of \\ Coimbra, Portugal \\ ${ }^{2}$ University of Coimbra, Portugal \\ ${ }^{3}$ Center for the study of migrations and intercultural relations, \\ Open University of Lisbon, Portugal \\ ${ }^{4}$ Department of Pedagogy, University of Granada, Spain \\ Correspondence: Albertina L Oliveira, Faculty of Psychology \\ and Educational Sciences of the University of Coimbra, Rua do \\ Colégio Novo, Coimbra, Portugal, Tel +35 I23985 I450, \\ Email aolima@fpce.uc.pt
}

Received: March 02, 2019 | Published: May 14, 2019

\section{Introduction}

The ageing of the population all over the world and especially in the more developed countries is not only a universal phenomenon but also irreversible, at least in the next decades. ${ }^{1,2}$ Portugal is currently the fourth most aged country of Europe ${ }^{1}$ (PORDATA, n.d.), which is the most aged continent in the world. ${ }^{2}$ The Portuguese men and women average life expectancy at birth is 78.1 and 84.3 years respectively, slightly higher than the average life expectancy at birth of the European Union. However, it turns out that the Portuguese seniors live more years with illnesses and physical disabilities than their fellow Europeans. That means that older Portuguese adults live with poor health and indirectly with less quality of life and well-being compared to older European adults. Thus, it is urgent to find ways to change this challenging reality.

The paradigm of active ageing claims more opportunities to improve health, participation in society and to increase the safety of all citizens so that quality of life can be ensured. However, the multidimensional nature of ageing seems to be reduced to an economic factor. ${ }^{3-5}$ José \& Teixeira, ${ }^{6}$ after reviewing several documents of the European Union, argue, on one hand, that they do not value the needs, interests and capacities of individuals and that, on the other hand, nonproductive activities are not being included. Walker ${ }^{3}$ points out that the political instruments that focus primarily on productive work and employment, as, for instance, lifelong learning in the context of active ageing, have been developed especially for training for employment, for working longer, for retiring later and gradually, i.e., the focus is not on the welfare of the ageing population. In our opinion, the criticisms made are not meant to finish with the paradigm of active ageing but with the aim of improving it. With this purpose in mind, among the main suggestions, we stress: the adoption of a more comprehensive, broader perspective, closer to the vision of WHO; fostering the active ageing perspective from the cradle to death-the best way to have an active and healthy ageing at advanced ages is prevention; helping people to accept the natural ageing changes and to integrate them in their lives; recognizing alternatives of ageing actively, and educating people about their potential and benefits across the lifespan. In order to advance toward these goals, research should listen to the older adults and promote quality participation in social activities that can really contribute to increase the quality of life, well-being and satisfaction with life of all generations. ${ }^{3-6}$

Intergenerational education is a kind of education that optimizes the possibilities of active ageing of individuals and populations, because it offers opportunities for participation in society, it increases social support networks and reduces isolation, it also increases the knowledge, skills and competencies, having as references the four pillars that structure lifelong education: learning to live together; learning to know; learning to do; and learning to be; ${ }^{7}$ it teaches diversity, tolerance, preserves valuable traditions and collective identity, it promotes solidarity, avoids violence and conflicts, encourages the collaborative commitment, innovation and constant upgrading of the new technologies, etc. ${ }^{8-10}$ Therefore, intergenerational education contains a great potential for the promotion of active ageing, centered on well-being and, consequently, on an effective quality of life for all citizens. ${ }^{11}$

\section{Methods}

In our work we have used for of the tree blocks of questions of the Questionnaire on the Needs, Interests and Potencial for Development of Intergenerational Programs (QNIPDPI) (Villas-Boas, 2018). From block I- Socio-demographic questions, we have used those relating to age, gender, from block II (social participation) and from block IV-Quality of Life, Health and for Social Support we have used the Lubben Social Network Scale (LSNS-6). The sample studied comprised 385 residents of the parish of Bonfim (Oporto), aged between 15 and 95 years old, divided into three age groups youngsters and young adults $[15-44$ years $](\mathrm{N}=110)$, middle-aged adults [45-64 years] $(\mathrm{N}=15)$ and older adults [65 or more years] $(\mathrm{N}=110)$. The overall sample was $57.1 \%$ female and $42.9 \%$ male. The sample, comprising $2 \%$ of the population of Bonfim (24.265 inhabitants), was obtained by non-probabilistic methods (convenience sampling). The questionnaire was applied in several places of the community whose directors gave consentient for the study, such as: schools, day-care centers, conviviality centers, study centers, nursing homes. The research was approved by the scientific council of the 
Faculty of Psychology and Educational Sciences of the University of Coimbra and by all participants and institutions involved who gave informed consent, according to deontological and ethical norms. Dr. James Lubben was asked to give his permission to use the instrument ${ }^{1}$. According to the objectives of our study, we use different types of statistical analysis, for the analysis of activities, descriptive analysis, for social support and QoL, we tested hypotheses by age group and sex, using the t-test and ANOVA. Statistical analyses were performed using the SPSS software, version 22. In all analyses, a significance level of 0.05 was considered.

\section{Results and discussion}

Regarding the participation of our sample in society and in leisure activities, we found that they tend to decrease with age. Concerning political participation, the interests of all age subgroups studied is low, however, it was observed that the voting frequency was higher in older adults. Similar results were found for Portugal in the study Active Ageing Index 2014. ${ }^{12}$ With regard to leisure activities, it was found that as age increases this type of activities become less frequent and that all groups in this community practice more often indoor leisure activities and individually. This raises some concerns, since the likelihood of young people and middle-age adults continuing to perform the same activities in later ages is great ${ }^{13,14}$ (Figure 1). These data show that it is essential to offer these population opportunities for involvement in physical and collective activities that promote social participation in order to foster active ageing. It was also found that the organizations, institutions and community associations are mostly frequented by different and separate age groups, which means that they offer few opportunities for intergeneration interactions. On the other hand, men showed to perform more leisure activities outside the home, what could be explained by having more free time than women, as the latter devote more time to the family life than men, ${ }^{15}$ and men are those who have more interest in politics. This field is, par excellence, a field of symbolic power that remains a stronghold of male domination, based on male values and standards. ${ }^{15}$

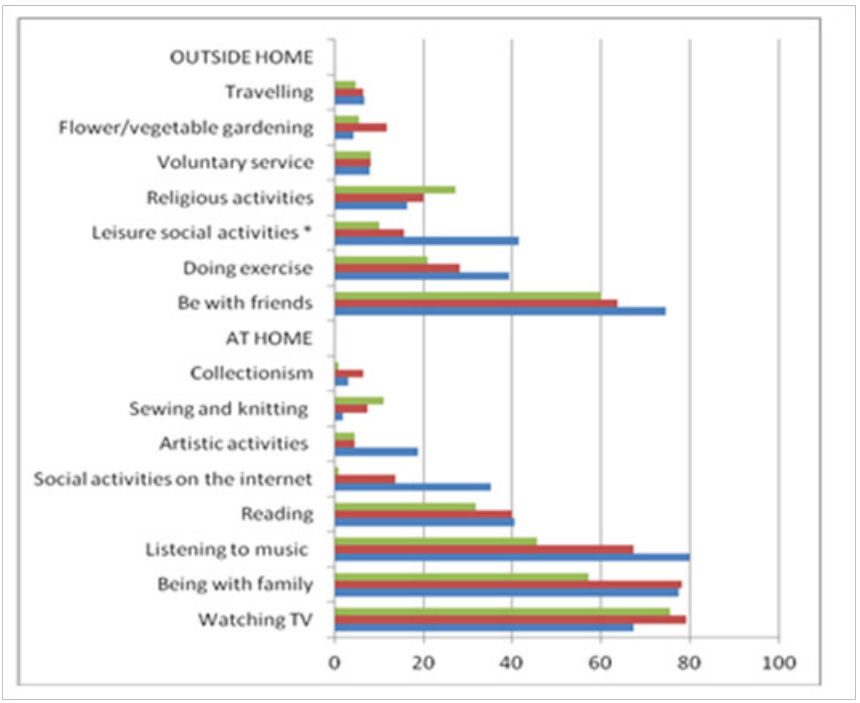

Figure I Outside and at home activities in which the 3 age groups are often involved (\%).

Legend $\square$,older adults (65 and more years); $\square$ middle-aged adults (45-64 years); $\square$ yound adults and adults (14-44 years)

*Go to the cinema, the restaurant, theater, etc.

From the analysis of participation in organizations and institutions of the community, it was evidenced that women attend more day centers and recreation centers-social responses of the Portuguese State-and male attend more associations and centers of culture and sports, organizations related to their personal interests.

With regard to social support, it tends also to decline with age, although the results have shown that there are people at risk of social isolation in all age subgroups (Table 1). Those who build less social support networks are women and they also live more situations of social isolation in the last phase of life. ${ }^{16}$ This seems to be the result of women being still playing a predominant role in the family, i.e., supporting, organizing, caring for the health of close relatives, for the education of children, among other tasks, and so becoming 'home prisoners', decreasing social contact in extra-family contexts. ${ }^{17}$

Table I Results for social support according to the 3 age groups

\begin{tabular}{|c|c|c|c|c|c|}
\hline & $\mathbf{N}$ & $\mathbf{M}$ & SD & DF & F (sig.) \\
\hline \multicolumn{6}{|l|}{ LSNS-6 } \\
\hline $\begin{array}{l}\text { Young adults and adults } \\
\text { (15-44 years) }\end{array}$ & 165 & 17,6 & 5,41 & & \\
\hline $\begin{array}{l}\text { Middle-aged adults (45-64 } \\
\text { years) }\end{array}$ & 110 & 15,9 & 6,36 & 2 & $4,61(p=0,010)$ \\
\hline $\begin{array}{l}\text { Older adults ( } 65 \text { and } \\
\text { more years) }\end{array}$ & 110 & 15,5 & 6,63 & & \\
\hline \multicolumn{6}{|l|}{ Subscale LSNS-3 family } \\
\hline $\begin{array}{l}\text { Young adults and adults } \\
\text { (15-44 years) }\end{array}$ & 165 & 8,9 & 3,15 & & \\
\hline $\begin{array}{l}\text { Middle-aged adults (45-64 } \\
\text { years) }\end{array}$ & 110 & 8,2 & 3,65 & 2 & $3,5(p=0,03 I)$ \\
\hline $\begin{array}{l}\text { Older adults ( } 65 \text { and } \\
\text { more years) }\end{array}$ & 110 & 7,8 & 3,93 & & \\
\hline \multicolumn{6}{|l|}{ Subscale LSNS-3 friends } \\
\hline $\begin{array}{l}\text { Young adults and adults } \\
\text { (15-44 years) }\end{array}$ & 165 & 8,6 & 3,14 & & \\
\hline $\begin{array}{l}\text { Middle-aged adults (45-64 } \\
\text { years) }\end{array}$ & 110 & 7,7 & 3,75 & 2 & $3,12(p=0,045)$ \\
\hline $\begin{array}{l}\text { Older adults ( } 65 \text { and } \\
\text { more years) }\end{array}$ & 110 & 7,6 & 4,2 & & \\
\hline
\end{tabular}

The social support plays a key role in the well-being and satisfaction with life and, therefore, in the quality of life of individuals (QoL). The data resulting from the study concerning QoL show that as age increases the assessment of QoL tends to decrease, although there are persons in all age subgroups with positive and negative evaluations of their QoL, as well as in both sexes. Older women are less satisfied with their QoL than man: the analyses by age groups show that there are neither significant gender differences in the subsamples of the young adults $\left(\mathrm{t}_{(163)}=-0,560 ; \mathrm{p}=0,576\right)$ nor in the middle-aged adults $\left(\mathrm{t}_{(383)=} 1,697 ; \mathrm{p}=0,0932\right)$. However, in the older adults group the differences are statistically significant $\left(\mathrm{t}_{(108)}=2,001 ; \mathrm{p}=0,048\right)$, with men evaluating better their QoL. A possible explanation for this significant result is the fact that women live longer than men and with more disabilities.

\section{Conclusion}

The results found and discussed in this article show the need to promote active ageing in the community studied. From our standpoint as well as that of other authors, ${ }^{3-6}$ since ageing is a multidimensional phenomenon, strategies which focus on the well-being of the population from a holistic perspective should be enhanced. Our proposal is the development of intergenerational education, departing 
from what the different generations have in common (goals, interests, feelings, sensations, and thoughts), stressing cooperation, empathic dialogue, debates and reflections. Intergenerational education helps to raise understanding about individuals lives and the lives of other members of the community, gives opportunity to people with different lifestyles (older adults, adults and youth, women and men, rich and poor, educated and less educated, among others) to think and act together, becoming sources of guidance, support and empowerment. In these programs participants usually increase their self-esteem and confidence, learn and acquire new behaviors, attitudes, values and skills, which help them to overcome difficult life conditions, contributing to increased well-being, satisfaction with life, social participation, in other words, quality of life. ${ }^{i}$

\section{Acknowledgments}

Fundação para a Ciência e Tecnologia (FCT).

\section{Conflicts of interest}

No conflict of interest has been declared by the authors.

${ }^{1}$ On the Boston College website at http://www.bc.edu/bc-web/about.html

\section{References}

1. https://www.pordata.pt/Europa/\%c3\%8dndice+de+envelhecimento-1609

2. http://www.un.org/en/development/desa/population/publications/pdf/ ageing/WorldPopulationAgeing2013.pdf

3. Walker A. Commentary: The emergence and application of active aging in Europe. Journal of Aging \& Social Policy. 2009;21(1):75-93.

4. Boudiny K. Active ageing: From empty rhetoric to effective policy tool Ageing \& Society. 2013;33:1-22.

5. Moulaert T, Paris M. Social policy on ageing: The case of «Active Ageing» as a theatrical metaphor. International Journal of Social Science Studies. 2013;1(2):113-123.

6. São José J, Teixeira A. Envelhecimento ativo: Contributo para uma discussão crítica. Análise Social,.2014; XLIX $\left(1^{\circ}\right): 28-54$.
7. Delors J. Educação, um tesouro a descobrir: relatório para a UNESCO da comissão internacional sobre educação para o século XXI. Porto: Edições ASA. 1996.

8. Gamliel T, Gabay N. Knowledge exchange, social interactions, and empowerment in a intergenerational technology program at school. Educational Gerontology. 2014;40:597-617.

9. Tam M. Intergenerational service learning between the old and young: what, why and how. Educational Gerontology. 2014;40(6):401-413.

10. Teater B. Intergenerational programs to promote active ageing: The experiences and perspectives of older adults. Activities, Adaptation \& Ageing. 2016;40(1):1-19.

11. Villas-Boas S. Educação intergeracional como estratégia de promoção do envelhecimento ativo : análise de necessidades de uma comunidade local, enquanto via fundamentadora de projetos relevantes e sustentáveis. Tese de Doutoramento, Universidade de Coimbra; 2018.

12. http://www.uis.unesco.org/Education/Documents/incheon-frameworkfor-action-en.pdf

13. Aartsen M, Smits C, Tilburg TV, et al. Activity in older adults: cause or consequences of cognitive functioning? A longitudinal study on everyday activities and cognitive performance in older adults. The Journals of Gerontology, Series B: Psychological Sciences and Social Sciences. 2012;57(2):153-162.

14. Agahi N, Ahacic K, Parker M. Continuity of leisure participation from middle age to old age. The Journals of Gerontology, Series B: Psychological Sciences and Social Sciences. 2006;61(6):340-346.

15. European institute for gender equality -EIGE. Gender equality index 2015: measuring gender equality in the European union 2005-2012;2015.

16. Stringhini S, Berkman L, Dugravot A, et al. Socioeconomic status, structural and functional measures of social support, and mortality - The British Whitehall II Cohort Study, 1985-2009. American Journal of Epidemiology. 2012;175(12):1275-1283.

17. Pinto J, Garcia A, Bocchi S, et al. Características do apoio social oferecido a idosos de área rural assistida pelo PSF. Ciência e Saúde Coletiva. 2006;11(3):753-764. 